\author{
ACTA MYCOLOGICA \\ Vol. 45 (1): 11-16 \\ 2010
}

\title{
Bibliography of publications by Barbara Gumińska
}

\author{
WŁADYSŁAW WOJEWODA ${ }^{1}$ and PIOTR MLECZKO² \\ ${ }^{1}$ W. Szafer Institute of Botany, Polish Academy of Sciences, Lubicz 46, PL-31-512 Kraków \\ ${ }^{2}$ Institute of Botany, Jagiellonian University, Lubicz 46, PL-31-512 Kraków
}

We present the complete list of publications by Professor Barbara Gumińska, published in the period 1953-2009. It contains oryginal papers, monographs, scientific notes, books, book chapters and articles for the general public. The bibliography is arranged in chronological order. Titles of papers written only in Polish have been translated into English, and the publications are marked "in Polish". Book reviews follow original and other papers in each year.

1953. Nowe stanowisko trufli w Pieninach. [New locality of truffle in Pieniny Mts.]. Chrońmy Przyrodę Ojczystą 9 (3): 40 (as B. Lubelska; in Polish).

1954. O występowaniu trufli (Tuber Mich. i Choiromyces Vitt.) w Polsce [The occurrence of the Truffle (Tuber Mich. and Choiromyces Vitt.) in Poland]. Fragmenta Floristica et Geobotanica 1 (1): 87-95 (as B. Lubelska; in Polish with English summary).

1956. Grzyby przyczyniające się do zamierania lasu osłabionego pożarem [Fungi contributing to the die-back of a forest weakened by fire]. Fragmenta Floristica et Geobotanica 2 (2): 112-133 (as B. Lubelska-Gumińska; in Polish with English summary).

1957. Repeated findings of the fungus Wawelia regia Namysł. in Cracow. Bulletin de l'Académie Polonaise des Sciences Cl. II. 5 (10): 347-348.

1958. Karel Cejp, Houby I. Praha 1957. Wiadomości Botaniczne 2 (2): 87 (a review; in Polish).

1959. Phylloporus rhodoxanthus (Schw.) Bres. w Polsce [Phylloporus rhodoxanthus (Schw.) Bres. in Poland]. Fragmenta Floristica et Geobotanica 5 (1): 151154 (in Polish with English summary).

- $\quad$ Wycieczka mikologiczna w Bieszczady [Mycological excursion to Bieszczady Mts.]. Wiadomości Botaniczne 1959 (2): 136 (in Polish).

- $\quad$ Karel Cejp, Houby II. Praha 1958. Wiadomości Botaniczne 3 (4): 242-243. (a review; in Polish).

1960. (Domański S., Gumińska B., Lisiewska M., Nespiak A., Skirgiełło A., Truszkowska W.) Mikoflora Bieszczadów Zachodnich (Wetlina 1958) [Mycoflore 
des Bieszczady Occidentales (Wetlina 1958)]. Monographiae Botanicae 10 (2): 159-237 (in Polish with French summary).

- Valentina and Gordon R. Wasson: Mushrooms, Russia and History. Pantheon Books, New York 1957. Str. 433, rycin 28, tablic 82. Wiadomości Botaniczne 4 (2): 242-243 (a review; in Polish).

1961. Purchawka olbrzymia - największy grzyb na świecie [Calvatia gigantea - the largest fungus of the world]. Chrońmy Przyrodę Ojczystą 17 (5): 16-18 (in Polish).

- $\quad$ Alina Skirgiełło: Grzyby (Fungi) - Podstawczaki (Basidiomycetes) Borowikowe (Boletales). Flora Polska, Rośliny Zarodnikowe Polski i Ziem Ościennych. Instytut Botaniki Polskiej Akademii Nauk, PWN, Warszawa 1960. Stron 130, tablic kolorowych 30, rycin kreskowych 47. Wiadomości Botaniczne 5 (3): 265 (a review; in Polish).

1962. Grzyby Roztoki Małej w Beskidzie Sądeckim [Fungi of Roztoka Mała in the Beskid Sądecki Mts.]. Fragmenta Floristica et Geobotanica 8 (2): 205-213 (in Polish with English summary).

- Mikoflora lasów bukowych Rabsztyna i Maciejowej (Studium florystycznoekologiczne) [The fungi of the beech forests of Rabsztyn and Maciejowa (a study of floristic and ecological conditions). Monographiae Botanicae 13: 3-85 + 6 tables (in Polish with English summary).

1963. (Domański S., Gumińska B., Lisiewska M., Nespiak A., Skirgiełło A., Truszkowska W.) Mikoflora Bieszczadów Zachodnich . II. (Ustrzyki Górne 1960) [Mycoflora of West Bieszczady. II]. Monographiae Botanicae 15: 3-75 (in Polish with English summary).

- $\quad$ Parki Narodowe i rezerwaty jako tereny nowszych badań mikologicznych [National Parks and Nature Reserves as territories of recent mycological investigations]. Chrońmy Przyrodę Ojczystą 19 (3): 7-13 (in Polish).

1965. Grzyby rosnace pod ziemią i ich rola w przyrodzie [Hypogeous fungi and their importnace in nature]. Chrońmy Przyrodę Ojczystą 21 (6): 20-24 (in Polish).

1966. Mikoflora lasów jodłowych okolic Muszyny [Mycoflora of the fir forests of Muszyna]. Acta Mycologica 2: 107-149 (in Polish with English summary).

- $\quad$ O kilku grzybach lasu jodłowego. Wszechświat 6: 140-142 (in Polish).

- $\quad$ Der Pieniny National Park. (In:) Czwarty Kongres Europejskich Mikologów. Guide quatrième Congrès des Mycologues Européens. Warszawa, p. 99105.

- $\quad$ (Gumińska B., Nespiak A.) Auf der Strecke Zakopane-Szczawnica-Zakopane. (In:) Czwarty Kongres Europejskich Mikologów. Guide quatrième Congrès des Mycologues Européens. Warszawa, p. 97-98.

- $\quad$ Lászlo Szemere: Die unterirdische Pilze des Karpatenbeckens (Fungi Hypogaei territorii Carpato-Pannonici). Nakładem Akadémiai Kiadó, Budapest 1965. Stron 319, w tekście 8 czarno-białych rysunków, przy końcu książki 10 kolorowych tablic. Wiadomości Botaniczne 10 (4): 281-283 (a review; in Polish).

1967. (Domański S., Gumińska B., Lisiewska M., Nespiak A., Skirgiełło A., Truszkowska W.) Mikoflora Bieszczadów Zachodnich. III (Baligród 1962) [Mycoflora of West Bieszczady. III]. Acta Mycologica 3: 63-114 (in Polish). 
- $\quad$ O leśnych grzybach workowych [About forest ascomycetes]. Wszechświat 7: 57-61 (in Polish).

1968. Sarcosphaera eximia (Dur. et Lév.) R. Mre. w Pienińskim Parku Narodowym [Sarcosphaera eximia (Dur. et Lév.) R. Mre. in the Pieniny National Park]. Acta Mycologica 4 (1): 131-146 (in Polish with English summary).

- $\quad$ (Gumińska B., Wojewoda W.) Grzyby owocnikowe i ich oznaczanie [Macrofungi and their identification]. PWRiL, Warszawa, p. 1-308 (in Polish).

1969. Mikoflora Pienińskiego Parku Narodowego (Część I) [Mycoflora of the Pieniny National Park (Part I)]. Acta Mycologica 5: 219-243 (in Polish with English summary).

1970. Rzadkie i nowe dla Polski grzyby z rodziny Hysterangiaceae znalezione w Pienińskim Parku Narodowym [Rare fungi of the family Hysterangiaceae found in the Pieniny National Park]. Fragmenta Floristica et Geobotanica 16 (3): 433-442 (in Polish with English summary).

1972. Nowe stanowisko Ischnoderma corrugis w Polsce [New locality of Ischnoderma corrugis in Poland]. Acta Mycologica 8 (1): 141-143 (in Polish with English summary).

- $\quad$ Mikoflora Pienińskiego Parku Narodowego (Część II) [Mycoflora of the Pieniny National Park (Part II)]. Acta Mycologica 8 (2): 149-174 (in Polish with English summary).

1973. Flora grzybów wielkoowocnikowych [Flora of macrofungi]. (In:) Przewodnik wycieczkowy 41 Zjazdu PTB [Excursion guide of $41^{\text {st }}$ Congress of the Polish Botanical Society]. Kraków, p. 17 (in Polish).

- $\quad$ I. Turowska, Z. Podbielkowski, W. Wojewoda: Rośliny zarodnikowe. Skrypt wydany przez Akademię Medyczną w Krakowie, Kraków 1971, tekst 195 stron, atlas 158 rycin na 51 stronach, cena skryptu + atlas 14 zł. Wiadomości Botaniczne 17 (1): 64-67 (a review; in Polish).

1974. Nowe stanowisko Stropharia albocrenulata (Peck.) Kreisel znalezione w Pieninach [New locality of Stropharia albocrenulata (Peck.) Kreisel in Poland]. Zeszyty Naukowe UJ, Prace Botaniczne 2: 201-208 (in Polish with English summary).

- $\quad$ Z badań nad mikoflorą Pienińskiego Parku Narodowego (wpływ warunków atmosferycznych na owocowanie grzybów) [Investigations on mycoflora of Pieniny National Park (influence of weather conditions on fructification of fungi)]. (In:) A. Skirgiełło, B. Sałata (eds) Materiały Ogólnopolskiego Sympozjum Mikologicznego [Materials of the Polish Mycological Symposium]. Lublin, p. 19-24 (in Polish).

1975. A. N. Wasiliewa: Agarikowyje szlapocznyje griby Primorskogo Kraja. Izd. „Nauka”, Akademia Nauk SSSR, Leningrad 1973, str. 328, 67 rys., 14 tabel, 2 tablice barwne. Wiadomości Botaniczne 19 (1): 328-329 (a review; in Polish).

1976. Mikoflora Pienińskiego Parku Narodowego (Część III) [Mycoflora of the Pieniny National Park (Part III)]. Zeszyty Naukowe UJ, Prace Botaniczne 4: 127-141 (in Polish with English summary).

- Macromycetes ląk w Pienińskim Parku Narodowym [Macromycetes of meadows in Pieniny National Park]. Acta Mycologica 12 (1): 3-75 (in Polish with English summary). 
1977. The locality of Onygena equina (Willd. ex S.F. Gray) Pers. ex Fr. in the suburbs of Cracow. Zeszyty Naukowe UJ, Prace Botaniczne 5: 153-156.

1980. M. Lisiewska, M. Szmid: Przewodnik grzyboznawczy, wyd. II zmienione, PWRiL, Warszawa 1980, 150 str., 74 ryc., 7 tabel. Wiadomości Botaniczne 24 (4): 293-294 (a review; in Polish).

1981. Mikoflora Pienińskiego Parku Narodowego (Część IV) [Mycoflora of the Pieniny National Park (Part IV)]. Zeszyty Naukowe UJ, Prace Botaniczne 9: 67-81 (in Polish).

- W. Rudnicka-Jezierska: Chaetomiales - Czuprynkowe; B. Sałata: Protomycetales - Pierwogrzybowe. Flora Polska, Rośliny Zarodnikowe Polski i Ziem Ościennych, Grzyby (Mycota), Workowce (Ascomycetes), Tom 12, PWN, Warszawa-Kraków 1979, 216 str., 97 ryc., 10 fotografii (w 3 tablicach). Wiadomości Botaniczne 25 (3): 234-235 (a review; in Polish).

1982. Grzyby kapeluszowe Pienińskiego Parku Narodowego [Mushrooms of the Pieniny National Park]. (In:) K. Zarzycki (ed.) Przyroda Pienin w obliczu zmian [Nature of Pieniny Mts in result of changes]. PWN, WarszawaKraków, p. 189-209 (in Polish).

- $\quad$ A. Skirgiełło, M. Zadara: Mucorales - Pleśniakowe; M. Ławrynowicz: Endogonales - Kłębiankowe, Flora Polska, Rośliny Zarodnikowe Polski i Ziem Ościennych, Grzyby (Mycota), Tom 10, PWN, Warszawa-Kraków 1979, 321 str., 97 ryc., 4 fotografie (w 2 tablicach). Wiadomości Botaniczne 26 (1/2): 70-71 (a review; in Polish).

- $\quad$ Michael E., Hennig B., Kreisel H.: Handbuch für Pilzfreunde Vierter Band. Blätterpilze - Dunkelblätter. Wydanie drugie. VEB G. Fischer Verlag Jena 1981, 472 str., 146 barwnych tablic (pojedynczych lub zbiorczych), 4 ryc., 16 fotografii czarno-białych i 7 mapek. Wiadomości Botaniczne 26 (3): 151 (a review; in Polish).

1983. (Gumińska B., Wojewoda W.) Grzyby i ich oznaczanie [Fungi and their identification]. Wydanie II, zmienione. PWRiL, Warszawa, p. 1-504 (in Polish).

- K. Wells, E. K. Wells: Basidium and Basidiocarp: Evolution, Cytology, Function and Development. Springer-Verlag, New York-Heidelberg-Berlin 1982, str. 187. Wiadomości Botaniczne 27 (1): 77-78 (a review; in Polish).

1984. (Gumińska B., Turnau K.) Repeated find of Lycogala flavo-fuscum (Ehrb.) Rost. in Cracow. Zeszyty Naukowe UJ, Prace Botaniczne 12: 181-184.

- J. Webster: Pilze. Eine Einführung. Springer-Verlag. Berlin-HeidelbergNew York 1983, str. 641, ryc. 332. Wiadomości Botaniczne 28 (1): 95-96 (a review; in Polish).

1985. Mutinus ravenelii (Berk. et Curt.) E. Fisher (Phallales, Mycota) - nowy gatunek dla flory Polski [Mutinus ravenelii (Berk. et Curt.) E. Fisher (Phallales, Mycota) - the species new to Poland]. Zeszyty Naukowe UJ, Prace Botaniczne 13: 97-103 (in Polish with English summary).

- $\quad$ (Gumińska B., Wojewoda W.) Grzyby i ich oznaczanie [Fungi and their identification]. Wydanie III. PWRiL, Warszawa, p. 1-305 (in Polish).

1987. Błąd w serii poświęconej grzybom [Error in the series with fungi]. Filatelista 34 (10): 237-238 (in Polish). 
- $\quad$ Odkrycie nowego gatunku grzyba z rodzaju Wawelia [The discovery of a new species of the genus Wawelia]. Wiadomości Botaniczne 31 (1): 9-13 (in Polish with English summary).

1988. Szybkość przyrastania „czarcich kręgów” na łące w okolicy Muszyny [Annual increase of ,fairy rings" in a meadow in the neighbourhood of Muszyna]. Acta Mycologica 24 (1): 51-58 (in Polish with English summary).

- $\quad$ Szybkość przyrastania „czarciego kręgu” na łące w okolicy Muszyny [Growth rate of „fairy rings" in a meadow near Muszyna]. Folia Societatis Scientiarum Lublinensis 30, Biologia 1-2: 21-22 (in Polish with English and Russian summaries).

- $\quad$ Mikologia w filatelistyce [Mycology in stumps-collecting]. Wszechświat 8 (3): 65-67 (in Polish).

- $\quad$ (Gumińska B., Wojewoda W.) Grzyby i ich oznaczanie [Fungi and their identification]. Wydanie IV. PWRiL, Warszawa, p. 1-505 (in Polish).

- J. Kochman: Zarys mikologii dla fitopatologów. 2 wydanie, poprawione i uzupełnione. Wydawnictwo SGGW-AR Warszawa 1986, 428 str., 234 ryc., 7 tabel, nakład 1000 egz. Wiadomości Botaniczne 32 (3): 186-187 (a review; in Polish).

- F. Kotlaba: Zeměpi sné rozšiřeni a ekologie chorošci (Polyporales s.1) v Československu. 194 str., 123 mapy, 86 fotografii w 36 tabelach. Československa Akademie Věd. Praha 1984, wydanie I. Wiadomości Botaniczne 32 (4): 250 (a review; in Polish).

1989. Macromycetes of the Pieniny National Park (a guide). (In:) $19^{\text {th }}$ International Phytogeographic Excursion 1989, July 7-26, "Flora and vegetation of Poland - Changes, Management and Conservation: 1928-1988". Institute of Botany, Polish Academy of Sciences, Kraków, p. 1-34.

- $\quad$ M. Semerdžieva, J. Veselský: Lečivé houby dřive a nyni. Praha 1986. Wydanie I. 177 str., 28 ryc., 2 tabele, 32 fotografie barwne. Československé akademie věd. Wiadomości Botaniczne 33 (1): 44-46 (a review; in Polish).

1990. Mikoflora Pienińskiego Parku Narodowego (Część V) [Mycoflora of the Pieniny National Park (Part V)]. Zeszyty Naukowe UJ, Prace Botaniczne 21: 157-172 (in Polish with English summary).

1991. (Gumińska B., Heinrich Z., Olech M.) Macromycetes of the NW Sørkapp Land, Spitsbergen. Polish Polar Research 12 (3): 407-417.

(Gumińska B., Marecka H.) Cis Taxus baccata L. w rezerwacie „Cisy w Malinówce" (województwo krośnieńskie) [Yew tree Taxus baccata L. in the „Cisy w Malinówce” nature reserve (district Krosno)]. Ochrona Przyrody 48: 105-119 (in Polish with English summary).

1992. (Gumińska B., Mierzeńska M.) Gerronema marchantiae Sing. et Clem. a fungus associating with Marchantia polymorpha L. and Nostoc sp. Zeszyty Naukowe UJ, Prace Botaniczne 24: 171-177.

- $\quad$ Higher fungi of the Tilio-Carpinetum forest association in the Skołczanka Reserve near Cracow. Acta Mycologica 27 (1): 137-158.

- $\quad$ Macromycetes of the Pieniny National Park (S. Poland). (In:) K. Zarzycki, E. Landolt, J.J. Wójcicki (eds) Contributions to the knowledge of flora and vegetation of Poland. Proceedings of the $19^{\text {th }}$ International Phytogeographic Excursion (IPE), 1989, through sounthern Poland. Volume 2. Flora 
and vegetation of the regions visited during the $19^{\text {th }}$ IPE. Present and former state. Veröffentlichungen des Geobotanischen Institutes ETH, Stiftung Rübel, Zürich, 107: 238-252.

- Grzyby wybranych łąk w Pienińskim Parku Narodowym - stan aktualny i warunki jego zachowania [Macromycetes of some meadows in the Pieniny National Park - the present state and suggestions for the future management]. Pieniny - Przyroda i Człowiek 2: 65-70 (in Polish with English summary).

- $\quad$ Kilka uwag o encyklopedii Guinessa [Some notes on the Guiness encyclopedia]. Wszechświat 93 (3): 84-85 (in Polish).

1994. Mikoflora Pienińskiego Parku Narodowego (Część VI) [Mycoflora of the Pieniny National Park (Part VI)]. Fragmenta Floristica et Geobotanica series Polonica 1: 33-39 (in Polish with English summary).

- $\quad$ (Gumińska B., Heinrich Z., Olech M.) Macromycetes of the South Shetland Islands (Antarctica). Polish Polar Research 15 (3-4): 103-109.

1997. Flora Polski. Grzyby (Mycota) 26: Podstawczaki (Basidiomycetes), Wodnichowate (Hygrophoraceae), Uniwersytet Jagielloński, Instytut Botaniki, Kraków, pp. 202, 22 pls. (in Polish with English key).

- $\quad$ (Dyląg E., Gumińska B.) Postfire macromycetes from deciduous wood in the Chrzanów forest inspectorate (S Poland). Acta Mycologica 32 (2): 173-187.

(Gumińska B., Turnau K.) Okazały owocnik grzyba podziemnego Choiromyces meandriformis Vitt. z Beskidu Wyspowego [Impressive fruitbody of the hypogeous fungus Choiromyces meandriformis Vitt. from Beskid Wyspowy Mts.]. Chrońmy Przyrodę Ojczystą 53 (2): 90-93 (in Polish).

1999. Mikoflora Pienińskiego Parku Narodowego (Część VII) [Mycoflora of the Pieniny National Park (Part VII)]. Fragmenta Floristica et Geobotanica series Polonica 6: 179-187 (in Polish with English summary).

2000. Grzyby wielkoowocnikowe (macromycetes). (In:) J. Razowski (ed.) Flora i fauna Pienin - Monografie Pienińskie 1: 47-53 (in Polish).

- $\quad$ Resupinatus kavinii (Tricholomataceae), a fungus species newly noted in Poland. Fragmenta Floristica et Geobotanica 45 (1-2): 509-512.

- Wawelia - historia i nowe odkrycia [Wawelia - the history and current news]. Wiadomości Botaniczne 44 (3-4): 23-25 (in Polish with English summary).

2002. New localities of two interesting species of fungi growing on sawdust. Polish Botanical Journal 47 (2): 139-142.

2004. (Gumińska B., Wojewoda W.) Mikoflora Pienińskiego Parku Narodowego (Część VIII) [Mycoflora of the Pieniny National Park (Part VIII)]. Fragmenta Floristica et Geobotanica series Polonica 11 (2): 371-382 (in Polish with English summary).

2006. Atlas grzybów Pienińskiego Parku Narodowego [Atlas of fungi of Pieniny National Park]. Wyd. Pieniński Park Narodowy, Krościenko n/Dunajcem, pp. 166 (in Polish).

2009. Aksamitka złota Pholiota aurea: grzyb rzadki w Polsce [Pholiota aurea: a rare fungus in Poland]. Chrońmy Przyrodę Ojczystą 65 (3): 205-208 (in Polish with English summary). 